\title{
Aminopeptidase N
}

National Cancer Institute

\section{Source}

National Cancer Institute. Aminopeptidase N. NCI Thesaurus. Code C94661.

Aminopeptidase N (967 aa, $110 \mathrm{kDa}$ ) is encoded by the human ANPEP gene. This protein plays a role in the mediation both of peptide hydrolysis and infection by certain viruses. 